\title{
LEVELS OF MINERALS IN THE BLOOD PLASMA OF COWS AND THEIR CALVES FED FROM BUCKETS
}

\author{
P. JAGOŠ, V. DVORÁK and J. BOUDA \\ Department of Diagnostics, Therapy and Prophylaxis of Animal Diseaes, \\ University of Veterinary Science, \\ 61242 Brno
}

Received May 16, 1980

\begin{abstract}
Jagoš P., V. Dvořák, J. Bouda: Levels of Minerals in the Blood Plasma of Cows and their Calves fed from Buckets. Acta vet. Brno, 50, 1981: 33-41.

The concentration in plasma of calcium, magnesium, inorganic phosphorus, zinc, copper and iron in $\mathbf{4 0}$ cows and their calves up to the age of three months was followed in winter season under conditions of large-scale technology. The statistically significant decrease in $\mathrm{Ca}$ concentration and the increase in $\mathbf{M g}$, inorganic $\mathbf{P}$ and $\mathrm{Fe}$ in blood plasma was found in pre-partum cows as compared with post-partum ones. No significant variations were found in $\mathrm{Zn}$ and $\mathrm{Cu}$ plasma levels both in pre- and post-partum cows. The concentration in urine of calcium, magnesium and inorganic phosphorus in post-partum cows when compared with the pre-partum levels was found to be insignificantly higher.

The plasma levels of calcium, inorganic phosphorus, zinc, copper and iron in calves prior to colostrum intake were higher than in their dams. The lowest plasma $\mathrm{Ca}, \mathrm{Mg}$, inorganic $\mathbf{P}$ and $\mathrm{Zn}$ contents were determined in calves from two to three weeks of age. The lowest $\mathrm{Cu}$ and $\mathrm{Fe}$ concentrations were found prior to colostrum intake and on the third day after birth, resp.

The highest mean values in calves, as determined during the three months' lasting experiment, were: plasma calcium $2.91 \pm 0.27 \mathrm{mmol} / 1$ (two months old), magnesium $0.95 \pm 0.10 \mathrm{mmol} / 1$ (age 1 day), inorganic phosphorus $3.52 \pm 1.0$ $\mathrm{mmol} / \mathrm{l}$ (prior to colostrum intake), iron $48.84 \pm 14.44 \mu \mathrm{mol} / 1$ (prior to colostrum intake), zinc $42.25 \pm 29.34 \mu \mathrm{mol} / 1$ (age 3 days), and copper $16.39 \pm 3.24 \mu \mathrm{mol} / 1$ (age three weeks).
\end{abstract}

Cow, calf, blood plasma, macroelements, trace elements, metabolism.

Both veterinary diagnostics, therapy and prophylaxis and rational management of animal production, mostly in large-scale cattle production, necessarily require elucidation of the metabolic processes. E. g. Dobšinský (1975) reports that metabolic disorders in calves in Czechoslovakia had been observed in $5.02 \%$, this percent being in fact higher owing to diagnostic difficulties. The study of macroelement metabolism has not only a scientific but also a practical significance in veterinary medicine. Many authors have investigated this problem in ruminants. The findings of Rowlands et al. (1974) suggest that even blood composition can usefully complement the selection of animals, possibly of breeds, in order to help to improve the growth potential. Little et al. (1977) have found a significant correlation between the weight gains, feed consumption and concentration of some blood metabolites. The increased weight of these followed calves correlated with serum concentration of iron as well. Payne et al. (1970) have reported on mineral metabolism in connection with performance of dairy cows. At our department we have examined the mineral levels not only in blood but also in urine, bone and other tissues and their relation to metabolic disorders (Jagoš et al. 1975a, b, c).

The modification of low magnesium intake in 800 cows reduced the calf mortality from $8-12 \%$ 
to $3 \%$ (Michel 1975). He also followed several groups of calves, 4-8 days old, and found that the deficiency of trace elements that act as enzymatic catalysts in biological processes was clinically manifested. The observed deficiencies were associated with dwarfism, increased disposition to diarrhea, originating probably in mother, fetal or colostral nutrition or in inadequate ability of calf to build up corresponding tissue reserves. The author also supposed that the used feed mixtures were not an adequate source of these minerals. If pregnant dams were treated, a significantly increased birth weight ( $2 \mathrm{~kg}$ in average) of calves and reduced morbidity when compared with control animals were observed (Michel 1975). Slanina et al. (1971) reported that inorganic phosphorus levels of calves born out of dams with inorganic $P$ deficiency in blood serum had dropped below the mean physiological standard, this finding not applying to plasma calcium.

The increased zinc content in a feed ration of pregnant dams brings about an increased level of this element in their born calves. The deficiency in cattle is manifested by hair loss, skin keratosis and by underdeveloped sexual organs (Labuda et al. 1975). Iron deficiency is in all species of farm animals accompanied by anemia, similarly as in the case of copper deficiency. When $\mathrm{Cu}$ is deficient bone structure and digestive tract disorders, manifested by diarrhea, and heart function disorders appear (Labuda et al. 1975).

Macroelement metabolism in connection with diarrhoea in calves has also been studied by a series of authors (Oplištil, Mašek 1967; Fischer, Butte 1974; Cabello, Michel 1977, etc.).

Calves with postnatal health disturbances differ by biochemical findings from healthy ones already at birth and probably also during their fetal life. When assaying phosphatemia, $72 \%$ of animals with inorganic $P$ concentration at birth being lower than $7 \mathrm{mg} / 100 \mathrm{ml}$ (i. e. $2.26 \mathrm{mmol} / \mathrm{l}$ ) suffered from diarrhea for several days following birth (Cabello, Michel 1977). These authors followed calves from birth to 20 days of age and found that calcemia and phosphatemia in scouring calves was always lower during this period when compared with healthy calves, these differences lasting at least 20 days. On the other hand, Fis cher and Butte (1974) who compared healthy and scouring calves found in the latter case the $\mathrm{Ca}, \mathrm{Mg}$ and inorganic $\mathrm{P}$ levels only slightly changed.

Jacobson (1972) reported on seventy known interrelations (synergism, antagonism, mutual conditionality). between minerals and stated that marginal mineral deficiencies led to reduced feed intake and in the case of lactating cows to lowered milk production.

In the present work we have aimed at so far not fully elucidated relations between dam and her progeny in the field of metabolism of some plasma minerals and trace elements. Clinically healthy cows in the last months of pregnancy and during the first month post partum were followed, the evaluation of the relation between mineral levels in mothers and calves up to the age of three months being the main task.

\section{Materials and Methods}

The experiment was conducted on 40 late pregnant cows and their 42 calves of Bohemian Spotted breed in a large-capacity cowhouse accomodating 600 heads. The clinical examination and blood sampling of cows was carried out 2-5 weeks prior to the expected date of delivery and 2-4 weeks post partum. At the same time urine samples were taken by catheterization. Immediately after birth the calves were transferred into individual cages in a prophylactorium and after 14-18 days they were moved into a calf-house. Twice a day the calves were given colostrum from buckets and from day 6 of age the calves were turned to a milk-replacer Laktosan A. The daily colostrum ration was 4-5 litres, that of milk; replacer Laktosan A 6-7 litres. The TK-1 mixture (concentrate) for calves was supplemented from the 11th day, meadow hay from three weeks of calf age. The mean body mass of calves prior to colostrum intake was $42.2 \mathrm{~kg}$. Their health condition was followed from birth to the age of three months. The blood samples were taken from v. jugularis prior to colostrum intake and then after 1, 3, 7, 21, 42, 56 and 84 days past the colostrum intake. Heparin was used as an anticoagulant agent for blood treatment.

The determination of calcium, magnesium, zinc, copper and iron levels in plasma of cows and their calves and in urine of cows was carried out using atomic absorption spectrophotometry. The content of inorganic phosphorus was determined photometrically using the Bio-la test (Lachema Brno).

The results obtained were evaluated on a Hewlett-Packard computer, model $9810 \mathrm{~A}$. To test the differences between individual samplings the method of simple split analysis and Duncan's test were used. 


\section{Results and Discussion}

The mean levels of individual macro- and trace elements in blood plasma of cows prior to and post partum and their interrelation are presented in Table 1 , indicating that statistically highly significant decrease in calcium was observed in blood plasma of post partum cows when compared with that of pre-partum cows. The drop of $\mathrm{Ca}$, inorganic $\mathrm{P}$ and the increase of plasma $\mathrm{Mg}$ post partum was also reported by Kirchner et al. (1977). The level of plasma zinc was found to be lowered in post partum cows, this being not statistically significant. The $\mathrm{Mg}$, inorganic $\mathrm{P}$ and $\mathrm{Fe}$ concentrations in the blood plasma of post partum cows were significantly higher in comparison with those of pre-partum cows, the $\mathrm{Ca}, \mathrm{Mg}$ and inorganic $\mathrm{P}$ levels in urine being also higher in post partum cows but when compared with pre partum data they were not statistically significant (Table 2).

Table 1

Mean levels of plasma macro- and trace elements in cows prior to and post parturition

\begin{tabular}{|c|c|c|c|}
\hline Element & Pre partum cows & Post partum cows & $\mathbf{P}$ \\
\hline $\begin{array}{l}\mathrm{Ca} \\
\mathrm{mmol} / 1 \\
\mathrm{Mg} \\
\mathrm{mmol} / 1 \\
\text { inorg. } \mathrm{P} \\
\mathrm{mmol} 1 \\
\mathrm{Zn} \\
\mu \mathrm{mol} / 1 \\
\mathrm{Cu} \\
\mu \mathrm{mol} / 1 \\
\mathrm{Fe} \\
\mu \mathrm{mol} / 1\end{array}$ & $\begin{aligned} 2.69 & \pm 0.14 \\
0.96 & \pm 0.08 \\
1.89 & \pm 0.24 \\
28.21 & \pm 12.84 \\
4.90 & \pm 2.91 \\
29.10 & \pm 6.42\end{aligned}$ & $\begin{aligned} 2.54 & \pm 0.15 \\
1.04 & \pm 010 \\
2.22 & \pm 0.30 \\
26.70 & \pm 12.38 \\
4.76 & \pm 2.17 \\
40.67 & \pm 10.01\end{aligned}$ & $\begin{array}{c}++ \\
++ \\
++ \\
- \\
- \\
++\end{array}$ \\
\hline
\end{tabular}

$\mathbf{P}<0.01=++$

$\mathbf{P}>0.05=-$

The values in all tables are given as mean $\pm S D$

Table 2

Mean levels of macroelements in urine of pre- and post partum cows

\begin{tabular}{|c|c|c|c|}
\hline Element & Pre partum cows & Post partum cows & P \\
\hline \begin{tabular}{l|c|}
$\mathrm{Ca}$ \\
$\mathrm{mmol} / 1$
\end{tabular} & $0.83 \pm 0.31$ & $1.05 \pm 0.82$ & - \\
$\begin{array}{l}\mathrm{Mg} \\
\text { mmol/1 } \\
\text { inorg. P } \\
\text { mmol/1 }\end{array}$ & $12.07 \pm 5.06$ & $13.45 \pm 4.69$ & - \\
\hline
\end{tabular}

$\mathbf{P}<0.01=++$

$\mathbf{P}>0.05=-$

The dynamics of mean levels of plasma elements in individual samplings is given in Tables 3 and 4 . With the exception of $\mathrm{Mg}$ the mean levels of all determined plasmatic macro- and trace elements in calves at the first examination, i. e. prior to colostrum intake, were higher than in their dams. The higher concentration of $\mathrm{Ca}$ and inorganic $\mathrm{P}$ in early postnatal period of calves when compared with adult cattle was also found by Cabello and Michel (1977). Similar differences in $\mathrm{Ca}, \mathrm{Mg}$ and inorganic $\mathrm{P}$ levels between a dam and her 
Table 3

Mean concentrations of plasma macroelements (mmol/1)

\begin{tabular}{|c|c|c|c|c|}
\hline Animal & $\begin{array}{c}\text { Age } \\
\text { (days) }\end{array}$ & $\mathrm{Ca}$ & $\mathrm{Mg}$ & Inorg. P \\
\hline Cows & Pre partum & $2.69 \pm 0.14$ & $0.96 \pm 0.08$ & $1.89 \pm 0.24$ \\
Calves (C) & Without colostrum & $2.76 \pm 0.18$ & $0.89 \pm 0.14$ & $3.52 \pm 1.00$ \\
C & 1 & $2.69 \pm 0.20$ & $0.95 \pm 0.10$ & $2.69 \pm 0.43$ \\
C & 3 & $2.76 \pm 0.26$ & $0.84 \pm 0.11$ & $2.75 \pm 0.59$ \\
C & 57 & $2.68 \pm 0.24$ & $0.82 \pm 0.13$ & $2.69 \pm 0.12$ \\
C & 14 & $2.59 \pm 0.20$ & $0.80 \pm 0.11$ & $2.56 \pm 0.23$ \\
C & 21 & $2.70 \pm 0.31$ & $0.79 \pm 0.08$ & 0.25 \\
C & 52 & $2.70 \pm 0.16$ & $0.90 \pm 0.07$ & $2.96 \pm 0.27$ \\
C & 56 & $2.76 \pm 0.27$ & $0.90 \pm 0.08$ & 0.27 \\
& & & $0.91 \pm 0.05$ & $0.97 \pm 0.30$ \\
\hline
\end{tabular}

Table 4

Mean concentrations of plasma microelements ( $\mu \mathrm{mol} / \mathrm{l}$ )

\begin{tabular}{|c|c|c|c|c|}
\hline Animal & $\begin{array}{c}\text { Age } \\
\text { (days) }\end{array}$ & $\mathrm{Zn}$ & $\mathrm{Cu}$ & $\mathrm{Fe}$ \\
\hline Cows & Pre partum & $28.21 \pm 12.84$ & $4.90 \pm 2.91$ & $29.10 \pm 0.42$ \\
Calves (C) & Without colostrum & $\mathbf{4 0 . 8 5} 26.61$ & $\mathbf{7 . 9 3} \pm 1.93$ & $\mathbf{4 8 . 8 4} \pm 14.44$ \\
C & 1 & $39.16 \pm 25.32$ & $9.64 \pm 3.43$ & $38.59 \pm 21.25$ \\
C & 3 & $42.25 \pm 29.34$ & $13.93 \pm 3.93$ & $32.08 \pm 1168$ \\
C & $5-7$ & $39.42 \pm 24.39$ & $14.81 \pm 3.76$ & $36.50 \pm 15.50$ \\
C & 14 & $26.32 \pm 11.50$ & $14.90 \pm 3.24$ & $39.19 \pm 13.67$ \\
C & 21 & $21.97 \pm 11.50$ & $16.39 \pm 3.24$ & $37.77 \pm 19.15$ \\
C & 42 & $39.53 \pm 26.19$ & $13.50 \pm 1.99$ & $40.34 \pm 10.91$ \\
C & 56 & $25.59 \pm 10.64$ & $15.78 \pm 3.75$ & $29.89 \pm 11.35$ \\
\hline
\end{tabular}

progeny were observed by Slanina et al. (1971), Hajdu et al. (1977) but the absolute values reported by these authors differ one from another.

The mean concentration of plasma $\mathrm{Ca}$ in our experimental calves varied in the first week and then at the age of 14 days dropped to the lowest value of all. Later the concentration gradually increased, reaching its maximum in calves two months old $(2.91 \pm 0.27 \mathrm{mmol} / \mathrm{l})$. In the third month the observed mean value became identical with the initial value prior to colostrum intake.

The plasma $\mathrm{Mg}$ level gradually decreased from the first day of calf life, reaching the lowest value of $0.79 \pm 0.08 \mathrm{mmol} / 1$ in the third week. From the sixth week to the third month it progressively increased so that the last measured value in calves 3 months old was higher than that prior to colostrum intake. A similar tendency in variation of plasma levels of $\mathrm{Ca}$ and $\mathrm{Mg}$ was reported by Buttler et al. (1971), Dobšinský (1975), Little et al. (1977), Cabello and Michel (1977).

The amount of inorganic $P$ also gradually decreased from the initial high level, reaching the lowest limit of $2.56 \pm 0.23 \mathrm{mmol} / 1$ at the age of 2 weeks. With.the increasing age a rather significant increase appeared. The levels of these macroelements are in many cases very similar or almost identical with data reported for calves by Melichar et al. (1971), Slanina et al. (1971), Barlet et al. (1971), Michel and Dardillat (1972). The comparison, using the t-test (P), of mean levels of plasma macroelements between individual samplings is summarized in Table 5.

When plasma zinc levels of calves (prior to colostrum intake) and their dams 
Table 5

Comparison of mean concentrations of plasma $\mathrm{Ca}, \mathrm{Mg}$ and inorg. $\mathrm{P}$ between individual samplings using the t-test (P)

\begin{tabular}{|c|c|c|c|c|c|c|c|c|c|c|}
\hline Animal & $\begin{array}{c}\text { Age } \\
\text { (days) }\end{array}$ & $\begin{array}{c}\text { C } \\
\text { With- } \\
\text { out } \\
\text { colo- } \\
\text { strum }\end{array}$ & $\begin{array}{l}\mathrm{C} \\
1\end{array}$ & $\begin{array}{l}\mathrm{C} \\
3\end{array}$ & $\begin{array}{c}\mathrm{C} \\
5-7\end{array}$ & $\begin{array}{l}C \\
14\end{array}$ & $\begin{array}{l}\mathrm{C} \\
21\end{array}$ & $\begin{array}{l}\mathrm{C} \\
42\end{array}$ & $\begin{array}{c}C \\
56\end{array}$ & $\begin{array}{l}C \\
84\end{array}$ \\
\hline Cows & Pre partum & 0 & 0 & 0 & 0 & 0 & 0 & 0 & 0 & 0 \\
\hline Calves (C) & $\begin{array}{l}\text { Without } \\
\text { colostrum }\end{array}$ & & $\begin{array}{l}\overline{+} \\
+\end{array}$ & $\begin{array}{l}\overline{+} \\
++\end{array}$ & $\begin{array}{l}\overline{+} \\
++\end{array}$ & $\begin{array}{l}++ \\
++ \\
++\end{array}$ & $\begin{array}{l}\overline{+} \\
++\end{array}$ & $\frac{t}{++}$ & $\frac{+}{++}$ & $\overline{-}+$ \\
\hline C & 1 & & & $\bar{t}+$ & $\overline{+}+$ & $\begin{array}{l}+ \\
+ \\
+\end{array}$ & $\overline{+}+$ & $\begin{array}{l}- \\
++ \\
++\end{array}$ & $\begin{array}{l}++ \\
+ \\
++\end{array}$ & $\begin{array}{l}\overline{+} \\
++\end{array}$ \\
\hline C & 3 & & & & $\bar{I}$ & $\frac{+}{+}$ & \pm & $\overline{ \pm}+$ & $\begin{array}{l}\overline{+}+ \\
+\end{array}$ & $\begin{array}{l}\overline{+}+ \\
+\end{array}$ \\
\hline C & $5-7$ & & & & & $\frac{+}{+}$ & $\bar{z}$ & $\begin{array}{l}- \\
++ \\
++\end{array}$ & $\begin{array}{l}++ \\
++ \\
++\end{array}$ & $\begin{array}{l}\overline{+}+ \\
++\end{array}$ \\
\hline C & 14 & & & & & & $\frac{ \pm}{++}$ & $\begin{array}{l}++ \\
++ \\
++\end{array}$ & $\begin{array}{l}++ \\
++ \\
++\end{array}$ & $\begin{array}{l}++ \\
++ \\
++\end{array}$ \\
\hline C & 21 & & & & & & & $\overline{t+}$ & $\stackrel{+}{++}$ & $\bar{t}+$ \\
\hline C & 42 & & & & & & & & $\begin{array}{l}++ \\
-\end{array}$ & $\bar{z}$ \\
\hline C & 56 & & & & & & & & & $\begin{array}{l}\bar{z} \\
\overline{-}\end{array}$ \\
\hline
\end{tabular}

Note: $\quad P<0.01=++$

$\mathbf{P}<0.05=+\quad P>0.05=-$

Not examined $=0$

$+,-=\mathrm{Ca}:$ lst rov

$+,-=\mathrm{Mg}: 2 \mathrm{vd}$ row

,$+-=$ inorg. $P$ : 3rd row

were compared, the former was found to be higher by $12 \mu \mathrm{mol} / 1$. It can generally be said that bodies of young animals contain less zinc that those of mature animals (Labuda et al. 1975). Taking into account this fact, it can be assumed that the increased deposition of this microelement in tissues occurs probably during the first weeks of life. Both this fact and the lower supply of this element in feed result in zinc concentration decrease in blood. The lowest value, similarly as in other elements, was observed at the age of three weeks $(21.97 \pm 11.50 \mu \mathrm{mol} / \mathrm{l})$. At the age of two and three months the zinc level in calf plasma stabilized approximately at the values found in cows, these values being, nevertheless, higher than those reported for cows by Michel (1975), Kudrjavcev and Kudrjavceva (1972). 
Table 6

Comparison of mean concentrations of plasma $\mathrm{Zn}, \mathrm{Cu}$ and $\mathrm{Fe}$ between individual samplings using the t-test (P)

\begin{tabular}{|c|c|c|c|c|c|c|c|c|c|c|}
\hline Animal & $\begin{array}{c}\text { Age } \\
\text { (days) }\end{array}$ & $\begin{array}{c}\mathrm{C} \\
\text { With- } \\
\text { out } \\
\text { colo- } \\
\text { strum }\end{array}$ & $\begin{array}{l}\mathrm{C} \\
1\end{array}$ & $\begin{array}{l}\mathbf{C} \\
3\end{array}$ & $\underset{5-7}{C}$ & $\underset{14}{C}$ & $\underset{21}{\mathrm{C}}$ & $\begin{array}{l}\mathrm{C} \\
42\end{array}$ & $\begin{array}{l}\mathrm{C} \\
56\end{array}$ & $\begin{array}{l}C \\
84\end{array}$ \\
\hline Cows & Pre partum & $\stackrel{+}{+}+$ & $\stackrel{+}{+}$ & $\begin{array}{l}++ \\
++\end{array}$ & $\stackrel{+}{++}$ & $\overrightarrow{+}+$ & $\stackrel{+}{++}$ & $\stackrel{+}{+}$ & $\bar{t}+$ & - \\
\hline Calves (C) & $\begin{array}{l}\text { Without } \\
\text { colostrum }\end{array}$ & + & $\begin{array}{l}\overrightarrow{+}+ \\
+\end{array}$ & $\begin{array}{l}- \\
++ \\
++\end{array}$ & $\begin{array}{l}\overline{+}+ \\
++\end{array}$ & $\begin{array}{l}++ \\
++ \\
++\end{array}$ & $\begin{array}{l}++ \\
++ \\
+\end{array}$ & $\begin{array}{l}- \\
++ \\
++\end{array}$ & $\begin{array}{l}++ \\
++ \\
++\end{array}$ & ++ \\
\hline C & 1 & & & $\overrightarrow{+}+$ & $\dot{\overrightarrow{+}}+$ & $\begin{array}{l}++ \\
++ \\
-\end{array}$ & $\begin{array}{l}++ \\
+ \\
+\end{array}$ & \pm & $\begin{array}{l}++ \\
++ \\
+\end{array}$ & ++ \\
\hline C & 3 & & & & $\bar{z}$ & $\frac{+}{+}+$ & $\begin{array}{l}++ \\
+ \\
+\end{array}$ & $\bar{t}$ & $\begin{array}{l}++ \\
\pm\end{array}$ & ++ \\
\hline C & $5-7$ & & & & & $\begin{array}{l} \pm+ \\
\pm\end{array}$ & $\begin{array}{l}++ \\
\pm\end{array}$ & \pm & $\frac{t+}{t}$ & ++ \\
\hline C & 14 & & . & & & & $\begin{array}{l}+ \\
\pm\end{array}$ & $\begin{array}{l}++ \\
\pm\end{array}$ & $\overline{-}$ & - \\
\hline C & 21 & & & & & & & $\begin{array}{l}++ \\
++ \\
+\end{array}$ & $\overline{-}$ & ++ \\
\hline C & 42 & & & & & & & & $\begin{array}{l}++ \\
++ \\
++\end{array}$ & ++ \\
\hline C & 56 & & & & & $\therefore$ & & & & - \\
\hline
\end{tabular}

Note: $\begin{aligned} & \mathrm{P}<0.01=++ \\ & +,-=\mathrm{Zn}: 1 \text { st row }\end{aligned}$

$P<0.05=+$

$P>0.05=$

$+,-=\mathrm{Zn}: 1$ st row $\quad+,-=\mathrm{Cu}: 2$ nd row $\quad+,-=\mathrm{Fe}: 3$ rd row

The copper level in the plasma of adult cattle, as reported by Sova et al. (1965), Michel (1975) and Slanina et al. (1977) ranges approximately from 13 to $20 \mu \mathrm{mol} / 1$. Considering this aspect the values of plasma copper in pregnant cows found by us conformed to a marked hypocupremia. The plasma copper concentration in the examined calves was at the time of first sampling prior to colostrum intake almost twice as high as that in the cows. This level increased gradually and reached the maximum value of $16.39 \pm 3.24 \mu \mathrm{mol} / 1$ at the age of three weeks, this concentration being almost quadruple of that observed in cows in the pre partum period. This finding in calves can be in connection with intensive hemopoiesis at this age. The $\mathrm{Cu}$ concentration in calf plasma stabilized at the values reported for adult cattle at the age of two and three months.

The iron content in calf body greatly varies and differs even between males and females of the same species (Labuda et al., 1975). Little et al. (1977) 
followed 30 heifers in weekly intervals up to the 13th week of age and found that with the increasing age the iron concentration in calf plasma had gradually increased during the whole period. We have not, however, observed this tendency when following approximately the same number of animals of both sexes. The iron concentration in the plasma of our experimental calves prior to colostrum intake was found to be by $20 \mu \mathrm{mol} / 1$ higher than in breeding cows and reached the values of $48.84 \pm 14.44 \mu \mathrm{mol} / 1$. The iron level decreased by one third up to the age of three days, then increased again, alternating from 30 to $40 \mu \mathrm{mol} / 1$ at the age of 3-6 weeks. This range is in agreement with findings of Slanina et al. (1977). The lowest value of $29.89 \pm 11.35 \mu \mathrm{mol} / 1$ was recorded in calves two months old.

The comparison of mean levels of plasma microelements between individual sampling in calves and their dams using the t-test $(P)$ is shown in Table 6.

The results of our work may be considered as a basis for further studies concerning the mother-calf relations during the last stage of pregnancy and early postnatal period, both in physiological and pathological conditions. These results can also be regarded as the starting material for studying the dynamics of metabolism development of some macro- and microelements in calves and various categories of young cattle. The knowledge to be obtained can be used both in preventive diagnostics and rationalization of animal nutrition, production and reproduction of health condition under industrial way of cattle husbandry.

\section{Hladiny minerálních látek v krevní plazmě krav a jejich telat napảjených $\mathrm{z}$ nádob}

V krevní plazmě 40 krav a jejich telat do stáři 3 měsíců byly $\mathrm{v}$ zimním období v podmínkách velkovýrobní technologie sledovány koncentrace $\mathrm{Ca}, \mathrm{Mg}$, anorg. $\mathrm{P}, \mathrm{Zn}, \mathrm{Cu}$ a $\mathrm{Fe}$. Statisticky významné snižení koncentrace $\mathrm{Ca}$ a významné zvýšení hladin $\mathrm{Mg}$, anorg. $\mathrm{P}$ a $\mathrm{Fe} \mathrm{v}$ krevní plazmě bylo zjištěno u krav po porodu oproti hodnotám před porodem. $V$ hladinách plazmatického zinku a mědi nebylo u dojnic před a po porodu významných rozdílů. Koncentrace $\mathrm{Ca}, \mathrm{Mg}$ a anorg. $\mathrm{P}$ v moči dojnic po porodu byly oproti hodnotám před porodem nevýznamně vyšší.

Plazmatické hladiny $\mathrm{Ca}$, anorg. $\mathrm{P}, \mathrm{Zn}, \mathrm{Cu}$ a $\mathrm{Fe}$ byly u telat před napitím kolostra vyšší než u jejich matek. Nejnižší hladiny plazmatického $\mathrm{Ca}, \mathrm{Mg}$, anorg. $\mathrm{P}$ a Zn byly nalezeny u telat ve stáŕí dvou až tří týdnů: $U$ mědi byla nalezena nejnižší koncentrace před napitím kolostra a u plazmatického železa třetí den po narození.

Nejvyšší průměrné zjištěné hodnoty během celého tříměsičního sledování telat činily u plazmatického $\mathrm{Ca} 2,91 \pm 0,27 \mathrm{mmol} / 1$ (stáří 2 měsíce), u hořčíku $0,95 \pm 0,10 \mathrm{mmol} / 1$ (stáŕí $1 \mathrm{den}$ ), u anorg. P 3,52 $\pm 1,0 \mathrm{mmol} / 1$ (před napitím kolostra), u Fe 48,84 $\pm 14,44 \mu$ mol/1 (před napitím kolostra), u Zn 42,25 $\pm 29,34$ $\mu \mathrm{mol} / 1$ (stáŕi 3 dny) a u mědi 16,39 $\pm 3,24 \mu \mathrm{mol} / 1$ (stáří tř́i týdny).

\section{Уровни минеральных веществ в крсвяной плазме коров и их телят, поенных из сосудов}

В кровяной плазме 40 коров и их телят в возрасте 3 месяца проводились в зимний период в условиях крупной промышленной технологии исследования концентрации Са, Мr, неорганического Р, Зн, Си, Фе. Статистически 
значимое понижение концентрации Са и сушественное повышение уровней $\mathrm{Mr}$, неорган. $\mathrm{P}$ и $Ф$ в в кровяной плазме было установлено у коров после отела по сравнению с величинами перед отелом. В уровнях плазматического пинка и меди у молочных коров перед и после отела не была выявлена сушественная разница. Концентрация $\mathrm{Ca}, \mathrm{Mr}$ и неорган. $\mathrm{P}$ в моче дойных коров после отела по сравнению с величинами до отела быыа несущественно выше.

Плазматические уровни Са, неорган. $\mathrm{P}$, Зн, Си и Яе у телят перед применением молозива были выше их матерей. Самые низкие уровни плазматического Са, Мr, неорган. Р и Зн были установлены у телят в возрасте двух-трех недель. Самая низкая величина концентрации меди перед приемом молозива и у плазматического мелеза была выявлена на третий день после отела.

Максимальные средние выявленные величины в течение всего трехмесячного периода исследования телят у плазматического Са составляли 2,91 \pm ‥ 0,27 ммоль/л (возраст 2 месяца), у магния -- 0,95 $\pm 0,10$ ммоль/л (возраст 1 день), у неорганического $\mathrm{P}-3,52 \pm 1,0$ ммоль/л (перед потреблением молозива), у Яе - 48,84 $\pm 14,44$ мкмоль/л (перед потреблением молозива), у Зн - 42,25 $\pm 29,34$ мкмоль/л (возраст 3 дня) и у меди $16,39 \pm 3,24$ мкмоль/л (возраст три недели).

\section{References}

BARLET, J. P. - MICHEL, M. C. - LARVOR, P. - THERIEZ, M.: Calcémie, phosphatémie, magnésémie et glycémie comparées de la mère et du nouveau-né chez les ruminants domestiques (vache, chèvre, brebis). Annals Biol. anim. Biochim. Biophys., 11, 1971: 415-426.

BUTLER, D. G. - WILlOUGHBY, R. A. - McSHERRY, B. J.: Studies on diarrhea in neonatal calves. III. Acid-base and serum electrolyte values in normal calves from birth to ten days of age. Can. J. comp. Med., 35, 1971: 36-39.

CABELLO, G. - MICHEL, M. C.: Composition of blood plasma (calcium, phosphorus, magnesium, proteins) during the neonatal period in the calf. Influence of the state of health. Annls Rech. vét., 8, 1977: 203-211.

DOBŠINSKYY, O.: Zdraví a produkční efekt v odchovu telat. Předneseno na celostátní konferenci „Prevence chorob telat“" 24. - 25. 9. 1975, Ceské Budějovice, Dům techniky CVTS.

FISCHER, W. - BUTTE, R.: Vergleichende Untersuchungen des Elektrolyt und Blutstatus bei gesunden und an Enteritis erkrankten Kälbern. Dte tierärztl. Wschr. 81, 1974: 594-604.

HAJDU, S̆. - BLAHO, R. - HEČKO, R.: Stúdium humorálného imunitného systému hovädzieho dobytka v postnatálnom období. II. čast. Imunoprofylaxia, Bratislava - Príroda, 4, 1977: 45-64.

JACOBSON, D. R. - HEMKEN, R. W. - BUTTON, F. S. - HATTON, R. H.: Mineral nutrition, calcium, phosphorus, magnesium and potassium interrelationships. J. Dairy Sci., 55, 1972: 935-944.

JAGOS, P. et al.: Skot - zdravotní problematika velkochovủ. Praha, SZN, 1975a: 279.

JAGOS, P. - ILLEK, J. - JURAJDOVÁ, J. - BOUDA, J. - HAMŠ́́, V. V. - DVORÁK, V.: Průzkum a vyhodnocení zdravotního stavu zvírat a veterinární prevence ve vybraných odchovnách. Project report, Brno, Vysoká škola veterinární. 1975b: 53 pp.

JAGOŠ, P. - ILLEK, J. - JURAJDOVÁ, J. - DVOŘÁK, V. - DOUBEK, J. - HAMŠ́f, V.: Výzkum karencí minerálních látek při metabolických poruchách. Project Report. Brno, Vysoká škola veterinární. $1975 \mathrm{c}: 175 \mathrm{pp}$.

KIRCHNER, K. - SCHULZ, O. - GROSSMANN, H.: Untersuchungen über das Verhalten einiger Stoffwechselparameter in geburtsnahen Zeitraum bei industriemässig gehaltenen Milchrindern. Mh. VetMed., 32, 1977: 566-568.

KUDRJAVCEV, A. A. - KUDRJAVCEVA, L. A.: Morfologičeskie i biochimičeskie pokazateli krovi i kostnogo mozga životnych. Vsesojuznyj ordena Lenina institut eksperimentalnoj veterinarii, Moskva, 1972: 19.

LABUDA, J. a kol.: Výživa a kŕmenie hospodárskych zvierat. Príroda, Bratislava, 1975: 530. 
LITTLE, W. - KAY, R. M. - MANSTRON, R. - ROWLANDS, G. J. - STARK, A. J.: The effect of age, live-weight gain and feed intake on the blood composition of young calves. J. agric. Sci., Cambridge, 89, 1977: 291-296.

MELICHAR, B. - DRESLER, J. - KUTÝ, A. - MAŠEK, J. - 'ROZKOŠNÝ, V.: Zvláštní případ hromadné dehydratace telat na mléčném výkrmu $\mathrm{v}$ letním období. Veterinářství, 21, 1971: $169-171$.

MICHEL, M. C.: Perinatal pathology of calves and metabolic profiles. Předneseno na konferenci „Perinatal ill - health in calves“ 22. 9. - 24. 9. 1975 - Institute for Research on Animal Disease, Compton, Great Britain, 1975.

MICHEL, M. C. - DARDILLAT, J.: Au quelques aspects de la pathologie néonatale du veau. Bull. Tech. C. R. Z. V. Theix, 7, 1972: 31-37.

OPLIŚTIL, M. - MAŠEK, J.: Biochemické studie při průjmech telat. I. Poruchy metabolismu elektrolytů. Docum. vet. (Brno), 6, 1976: 43-52.

PAYNE, J. M. - DEW, S. M. - MANSTON, R.: The use of a metabolic profile test to determine the nutrition and metabolic status of a dairy herd in relation to its production requirement. Lactation - International Symposium, Nottingham, 1970. Edited by J. A. Falconer, London, Butterworths, 1970, $467 \mathrm{p}$.

ROWLANDS, G. J. - PAYNE, J. M. - DEW, S. M. - MANSTON, R.: Individuality and heritability of the blood composition of calves with particular reference to the selection of stock with improved growth potential. J. agric. Sci., Cambridge, 82, 1974: 473-481.

SLANINA, L. et al.: Zdravie a chorobnost teliat v priemyselnej produkcii. Príroda, Bratislava, 1977: 335.

SLANINA, L. - SLABEJ, J. - SOKOL, J.: Stúdium niektorých vzájomných vztahov u dojníc a ich novorodených teliec. I. Hodnoty alkalickej rezervy krvnej plazmy a krvných elementov. Veterinářství, 21, 1971: 156-159.

SOVA, Z. - RADEMACHER, R. - JÍCHA, J. - VAR̆EJČKO, J.: Hematologické a biochemické standardy domácích zvírat. 2. sdělení: Standardy u skotu. Sborník Vysoké školy zemědělské, Praha, 1965: 567-570. 